\title{
Public Administration and Literature
}

\begin{abstract}
Ádám Rixer*
* Prof. Ádám Rixer, PhD, Head of the Department of Administrative Law, Faculty of Law, Károli Gáspár University of the Reformed Church in Hungary, Head of Lajos Lőrincz Research Centre for Public Law, member of the Subcommittee of Administrative Sciences of the Hungarian Academy of Sciences. (e-mail: rixer.adam@kre.hu)
\end{abstract}

\begin{abstract}
Nowadays Law and Literature courses become more and more popular worldwide; this is also true for Hungary. Examining these attempts, we may conclude that legal problems do reach the students through mainly fictitious literary stories instead of real cases. Accordingly, the idea of Public Administration and Literature courses can be proposed, as well. Among the reasons to introduce such courses we can detect new demands on the side of the students, the need for the methodological renewal of teaching and also the fact that the National University of Public Service already offers MA levels in administrative sciences. This paper - providing several examples - summarizes the main fields and subjects of public administration showed in fine literature and it also collects those genres by which administrative topics are most frequently introduced.
\end{abstract}

Keywords: Hungarian literature; indirect representation of administrative phenomena; law and literature; teaching public administration

\section{Introduction}

Nowadays the various Law and Literature courses are gaining popularity all over the world, including our country. If we analyse these trainings and experiments merely from a methodological point of view, we will see that these courses present legal issues not through real-life cases but through stories belonging to fiction, still showing some similarities with real life. The presentation and interpretation of each legal institution will be thus possible through a shared experience that would otherwise only partially be possible if using other conventional studies, as most students, especially in the Prussian type of educational environment, are unprepared or have limited professional preconceptions when attending a course or a seminar, and this gives unnecessarily large space for the teacher, who often, at least in Hungary, repeats at the seminars the extended version of the theory presented during the courses.

Similarly to the approach mirrored by the Law and Literature initiative the Public Administration and Literature course can also be taken into consideration as a possibility. In case we try to compare the well-known outlines of law and literature with the contours of the newly introduced concept (public administration and fiction), on the one hand we will find that the latter extends its investigations to a wider range because it goes beyond the law of public administration but on the other hand it is also possible to conclude that 
the subject of public administration and fiction is narrower than that of law and fiction, given that the non-strict administrative implications of the law are outside the interest of the researchers dealing with this domain. The apparent contradictions and tensions of these two approaches are very well overcome by the fact that the fictional representations of administrative phenomena appear to be predominantly in conflict with the ideals of these phenomena, as conceived by legal instruments, thus relativizing and blurring the theoretical boundaries between law and literature respectively between public administration and literature.

The question to which this study also seeks to answer can rise other questions: whether literary and legal texts can provide meaningful contexts to each other, and whether the study of texts belonging to one of these categories can have any benefit with respect to the interpretation of the texts belonging to the other category. ${ }^{1}$ Of course, it is not satisfactory to deal with this problem only from the perspective of intertextuality. ${ }^{2}$

This paper seeks to explore the possibilities of involving literary works in the formation of public administration students, listing the reasons and arguments that support the need for these kinds of approaches. It is obvious that first of all the contours of a theoretical framework should be created taking in consideration the justification of the existence of public administration and literature as a separate field of science. In addition to the theoretical challenges, the real, practical significance of the topic is increased by the fact that university education and doctoral training are also taking place in the Hungarian public administration professional training, thus - presumably - the necessity for the justification of methodological and didactic considerations is also increasing.

\section{The Concept of Science of Public Administration and the Transformation of Its Internal Structure}

The science of public administration can be mostly defined as a set of disciplines dealing with the same subject - that is public administration - with different scientific methods, while the diversity of approaches for each subject does not necessarily involve integrating and synthesizing partial results. That is why it is more accurate to talk about public administration disciplines and not about unified administration science.

However, among the public administration disciplines, some disciplines have a prominent, central role, which are called major branches of science by the scholarly literature, especially if their essential and central goal is to investigate the main context of public administration. Admittedly, administrative law, political science, or even organizational science may be included among the major branches of science. Those branches of science that are loosely associated with public administration or the latter is merely on the periphery of their research, or they focus only on some of the administrative phenomena, or on some of the narrower aspects of public administration - according to some authors - do not even belong to the public administration disciplines in their narrower sense, thus they are often considered interdisciplinary areas of science by the scholarly literature. ${ }^{3}$ These include some of the new areas, such as e-administration as an 
independent, interdisciplinary field of science. Public administration and literature as a field of study, in principle, might become one of the large numbers of these areas (each having different degree of importance). Public administration and literature, as we have already mentioned, is not sharply delimitated from the more traditional and more embedded area in Hungary that is law and literature.

We must also emphasize that traditionally in Hungary, both public administration and the science of public administration have an extremely legal character. However, this is partly natural, because the analysis of public administration with legal methods and having a fundamentally legal approach towards it is somehow obvious due to the fact that "the issues of public administration can be legally made unambiguous and their mechanisms have been deliberately established since the beginning of the $19^{\text {th }}$ century based on law, and this principle dominates the actual practice as well". ${ }^{4}$

Of course, legal approaches and descriptions cannot be exclusive; it is not advisable to come to a conclusion regarding actual changes in society only through changes in law. Quoting András Sajó: “The constraint of adaptation to the new and the over-emphasis of social control of law often indicates significant moves even in segments where nothing happens." Public administration and literature as an area of science is trying to reconcile the everyday reality of administrative law and society by using reality-related, but decisively fictive cases in the application of legal experience and in teaching legal history and in the same making inevitable the analysis of the connections from sociological, culturalanthropological, ethical and sometimes explicitly religious perspective. Nowadays, the relationship of other social sciences with literature is well documented (scientifically founded), e.g. for sociology and sociography, it is evident that certain basic literary works become the imprints of social and cultural life of the given crisis period and as important elements of the cultural life, they have strong impact even upon collective historical consciousness. $^{6}$

We can also summarize what has been written before by concluding that law is a part of people's everyday life regardless of the manner we define it: a set of normative rules that are compulsory for everybody or voluntary following of norms related to individual administrative decisions, or institutions that provide protection for the rights of clients, or behaviours defying norms - if these are present in the most common relations of everyday life, they must appear in the literary works that reproduce, represent and interpret these relations.

\section{From "Law and Literature" to "Public Administration and Literature"}

As we have just mentioned, the so-called law and literature is slowly becoming a separate discipline also in Hungary, intending to interpret and represent the fictional contexts and imprints of legal phenomena. According to the simplest - and perhaps the most commonly used - scheme in this research area, there can be distinguished two distinct basic approaches: one that analyses how law appears in literature and the other one that considers the law itself a particular literary genre (law as literature). ${ }^{7}$ 
The law in literature approach is closely linked to the criticism of law and state, ${ }^{8}$ and in addition to this fact the works of modern novel literature can serve as valuable sources for researches on legal sociology. Let's note that some trends in sociography can be seen as a kind of common cross-section of public administration in its broadest sense and fiction - Gyula Illyés's works being perhaps the best examples of this.?

We must not forget that the fundamental function of law is to maintain the community, that is why its essence stands in constitutive rhetoric - meaning that the retelling of the stories of the community members in a legal frame also contributes, as the final act of the legal conflict, to the integration or reintegration of the individual into the community, or help him find otherwise his homey, meaningful place. ${ }^{10}$ With some simplification, we may say that the primary purpose of both the administration and of fiction is the restoring of "order and the re-balancing the diseased equilibria". ${ }^{11}$

The relationship between law and literature has been in the focus of interest of legal scientists for a long time, several studies of the scholarly literature analyse the importance of the alternative use of this area and the need to develop relevant didactic tools in legal education. ${ }^{12}$ Through its stand-alone perspectives and tools the law and literature approach may make a useful contribution to the more precise presentation and interpretation of the content of legal texts and even of legal practice using well-crafted artistic examples.

In the meantime, we find that in the field of studying and teaching administrative phenomena, the legal-natured approach is still the dominant one, which emphasizes the descriptive presentation of rules and institutions. This approach, however, in itself does not give a complete picture of a particular issue of social reality (see the previously quoted study by András Sajó), thus getting acquainted with the community attitudes developed towards a particular institution, and with the individual motivations ${ }^{13}$ become essential to get an adequate picture of society (community meaning both the public administration staff and the customers).

Limiting or adapting the so far described aspects to public administration, we have to say that the emergence of structures, operations and personnel of a public administration having a highly legal character in older or contemporary literature can also contribute to a better and more scientific understanding (and research) of the real forms and directions of change of public administration, or of the repetitive features of the studied field. For now, these possibilities are only theoretical, substantive research on these contexts has not so far been conducted in Hungary.

\subsection{Arguments in Favour of Law and Literature}

There have been attempts to present the existing and possible forms of relationship between law and literature in Hungarian scholarly literature,${ }^{14}$ but the role of the area in legal and/ or administrative education needs further elaboration.

This modest writing intends to take the first and further steps in these two directions: on the one hand it presents the reasons that make this area acceptable and even in some respects necessary in the legal/administrative education; on the other hand, it presents the structured catalogue of the relationship between public administration and literature, 
making more accessible the main possibilities of systematization through concrete examples.

The transformation of the law and literature method to public administration and literature and its conscious incorporation into the curriculum of law schools and administrative faculties can be recommended for at least eight reasons:

1. It opens up a new communication channel for those who otherwise - or by other means - cannot be or can hardly be involved in the education process. This mode of knowledge transfer teaches through play, strengthening the concept of homo-ludens and minimizing the factor of constraint in the process of learning (while being appropriate for the achievement of the goals related to content);

creating and accepting new public social agreements is easier if the conveying of the desirable patterns is not made - exclusively - in a frontal manner, e.g. through teaching legal or other norms, but indirectly through the stories of imagined worlds. This method is performing similar functions as the tales for children: through the tale children will gain the knowledge of the distinction between good and bad.

2. It educates for life - meaning that it restores the original, natural, and most striking purpose of the academic higher education that is to prepare students for situations that are not closely related to professionalism but have at least the same importance, especially if we accept that the quality of life of the lawyer/administrative practitioner is not determined solely by professional success. It is sufficient here to look at the higher education goals set out in the 2007 London Communique towards the European Higher Education Area: instead of descriptive science, the new aspirations of education focus on cause and effect relationships aiming to offer a qualification for living in a democratic society, promoting self-realization and educating for life in a narrower meaning of the phrase and - in today's Hungarian usage - referring as well to the so-called training of intellectuals. The latter appears at Jakab as a special (main) goal amongst the aims of legal education, a goal meant to serve the "education of men with general culture". 15

Education for life also means that the training not only presents space- and timeisolated knowledge and forms of knowledge that can be used merely in a narrow area, but it takes into account the processuality, globality and particularly complex needs and expectations of the new age. This opens new horizons by which the classical, partly legal, partly independent framework for public administration education is stretched out by the concept of the so-called lifelong learning, which does not only involve preparation for public administration or professional exams (etc.), but also training courses tailored to specific sectors and in addition to these more and more education programs in other fields, too.

3. If one is trying to find the most important call words and goals of today's public administration and its staff, or if one wants to deduce these from the various official programs and plans, one of the most commonly used terms would certainly be integrity (in Hungary). Modernizing societies have increasingly established relationships - and upon these relationships there have been organized more expansive social forms - in which the participants became important only from one aspect while their personality as a whole was left out of these forms. Each individual thus participates with increasingly specialized roles in modern society, with the disciplined suppression of the rest of his personality, and it is 
this disciplined and socially structured interpretation of roles that the intricate complexity of the society rests on. ${ }^{16}$ It is therefore indispensable to show to people - in our case students of law schools and public administration faculties, public servants participating in professional training - that the process of becoming a lawyer/administrative expert and the acquisition of new law-enforcement skills is not just a role, or one of the future roles of the individual, but something that must express a unity with the other important roles, such as the most important areas of private life, of family relationships, and with a sound and clear world view, etc.

In this regard, it is also important to note that renunciation of a comprehensive philosophical worldview is an important symptom of the recent age. Thus, it seems unavoidable to re-create the philosophical synthesis between the legal norms governing public administration and the facts of its actual operation. It can be stated in general that, as a result of the crises, social sciences are increasingly forced to investigate the underlying meaning of things and the broader frameworks of the examined phenomena instead of the descriptive aspects of the mode of operation. In times of crisis, when our expectations are shaken by everyday experience, legal and political theory is also radicalized: it is forced to examine and rethink the validity of its own presumptions. Philosophizing gains justification again, since from the discourse of political theory (and the theory of public administration) that wants to act as a descriptive scientific discipline it is becoming increasingly difficult to exclude questions that are not related to the mode of operation, but to the meaning (i.e. the framework of interpretation). In the recent decades, legal and especially administrativejurisprudential thinking has not shifted towards philosophical reflection; it was satisfied with the questions and answers necessary from the perspective of practice. One of the impressions of this - in this particular field - is the dominance of commentary-literature as a genre.

We also have to face the wrong position, which seeks to reduce the ideas and proposals related to the renewal of legal training/professional training of public servants to the issue of practice or theory. ${ }^{17}$ It is worthwhile to mention that the training of legal practitioners/ public servants has a third element, that has a strong emphasis if related to the other two elements; this is the ethical and moral aspect that has been the most neglected area of the entire legal/administrative higher education in the last $60-65$ years. ${ }^{18}$

For illustrating, interpreting, and exemplifying these problems, it is very helpful to deal with the realistic and life-like dilemma or work-related and vocational difficulties of the literary heroes. Since the relationship between public administration and justice is not only a catalogue of ageless problems, but it is also reflected in situations that are very closely related to the age, situation and social constellation, a major pathway of law and literature and public administration and literature courses must obviously and necessarily be the study and interpretation of the works of contemporary literature. This, of course, does not mean the dethronement of classical and modern dramatic literature, or of the fiction of the $19^{\text {th }}-20^{\text {th }}$ centuries, but for the education and development of the reader (student), both synchronicity and the possibility of processing situations similar to personal ones related to personal reality have a decisive influence. Equally important is the clarification of the contemporary nature of literary works (conceptual narrowing): obviously, those literary projections and contemporary works have the strongest explanatory power on a subject that reflect the elements of the same (or at least similar) legal culture and wider social reality. That is to say, although Hungarian literature is only a small cross-section - at least 
compared to the entire universal literature - it is not negligible the continuous and analytic incorporation of contemporary Hungarian literature into the material and set of arguments of law and literature and public administration and literature courses.

4. Transforming attitudes of public administration, rendering values. The picture would not be complete without mentioning, for example, that the weaknesses and shortcomings of public institutions in contact with e.g. the Roma are often the results of the faulty attitudes, inappropriate interpretations of roles by the public administration personnel, etc. Defective attitudes cannot be changed exclusively by legal regulations, by performance assessment and monitoring, etc.; for the description of the mental state of the public servant and of the concrete social situation and of the interaction of these two, the methodology of social psychology can also be very useful. ${ }^{19}$ This modern social psychology is no longer exclusively aimed at restoring information asymmetries but rather attempts to promote profound value-changing (!), and outlines a complex socialization ${ }^{20}$ process in which one of the decisive elements of "mental programming is the overwriting of unwritten but valid public agreements and rules". ${ }^{21}$ The change, therefore, depends, partially, on the programs that, - referring to the example used at the beginning of this sub-chapter - do not specifically have an impact on Roma and Roma organizations, but they offer a "qualification for a transformed attitude on the side of public administration".22 In this process the role-play-based development focusing on active participation has or can have an inescapable role while another important factor is the discovery and the individual and group processing of literary parallels. Regardless of the manner in which we look at the possibilities (reasonableness) of the public administration and literature method, it is a fact that the number and the importance of the courses and issues related to ethics and integrity [see also sub-chapter 3. of this chapter] had grown lately, that indirectly also points to the fact that the need for the elaboration of truly new approaches and for the use of original methods is stronger than ever. ${ }^{23}$

5. We must also take into account the fact that the public servant working in public administration does not simply implement law, provide services and organize activities, but also encounters human conflicts, fates (losses), and in some cases he or she is as well involved.

Is it possible to resolve a dispute, settle any major legal issue in such a way as to exclude emotional difficulties and mental injuries from the process with complete certainty? Éva Ancsel writes - referring to Wittgenstein that "the education of today is aimed at reducing people's capacity for suffering". ${ }^{24}$ Quoting an American saying: "parents are happy if the children have a good time". Ancsel also adds that education reducing the capacity of suffering and any other impetus that is striving for compassion, at the same time blocks the path from the knowledge available through the experience of these feelings. ${ }^{25}$ While the literature teacher's vocation is to teach the students how to read, ${ }^{26}$ the teacher of legal and administrative sciences must be able to develop, strengthen, and establish the basis of the knowledge of law students and of future administration professionals in order to be altruistic in their future activity. If we remove this (main) function from legal and administrative training, it will mean that we support the view according to which it is possible to train legal and administrative practitioners only by e-learning and distance education without any personal presence, since most things are conveniently learnable from books and electronic interfaces. 
One of the possible forms of teaching how to mourn personal and community tragedies (i.e. the development of human responses expected in the service of the community) is the creation of a toolkit that permits experiencing and processing through literature and at the same time is partly independent from any worldview. In this case, the stories that appear to be fictitious and those that are realistic, but appear in a literary masque, will not only be simple legal cases that raise questions that can be easily answered with basic legal knowledge, but complex tasks - emphasizing legal contexts, as well - which will force students of public administration to totally reconsider (think over) the situation through real and inevitably personal relationships, to a certain extent, realizing the goals of self-knowledge and community knowledge of the current psycho-drama courses.

It is a matter of the teacher's attitude to what degree the law and literature/public administration and literature courses are characterized by the aspiration of moral education, and to what degree by the need to explore the new and emerging problems of interpretation, ${ }^{27}$ and consequently by the need to develop the basic legal and debating skills, or by the intent to create a sense of security that is essentially worthless and can be best expressed by the phrase "something I have heard". However, wherever the focus of training is placed, it is a fact that the explanation of legal/administrative institutions by literary works is not merely one of the possible aids to "acquire the material, but rather a new approach to legal-administrative communication that has the ability to redefine and refresh the ethical component of the law (and of the public-political sphere) by an overwhelming representation of diversity".28

If one takes a look at the scholarly literature, it is obvious that almost all the contemporary authors make proposals regarding the reform of legal and administrative education in which the decisive, sometimes exclusive, element would be the introduction of practice-oriented training. ${ }^{29}$ This is also consistent with the fact that, according to Hungarian experience, ${ }^{30}$ the most successful trainings in the field of public administration are those based on personal presence: "The strengths of this kind of training programs are practical elements, methodological solutions supporting experience-based learning. There is exceptionally good feedback from participants to training-based programs, where group cohesion between public servants increases, personal relationships are born, and selfknowledge is evolving beyond professional knowledge". ${ }^{31}$

These scientific conclusions also highlight the possibilities offered by the method of public administration and literature, and open the way for such and similar experimental programs.

6. Indirect exercising of text comprehension, text processing and verbal expression. In addition to the classical problems of our higher education (and generally our Hungarian education), new difficulties have also emerged and have become massive in the last decades. The spread of bad reading comprehension skills is added to old mistakes such as self-serving teaching of rules without lacking the undergrounding knowledge. Regarding the latter, Marcell Benedek says: "the curriculum will have goals completely different from the ones planned. It does not teach how to recognize the beauties, it teaches only rules and facts from which the pupil as a reader cannot draw any conclusions." 32

The training and output requirements of administrative professionals can be captured from the side of the social expectations raised towards them. In this circle, besides the 
willingness of compassion and the existence of professional knowledge, one of the legitimate expectations raised towards public servants working for the benefit of the community is to have very good oral communication skills and good writing skills making them able to produce texts without distorting effects using appropriate words, style, language, etc., and avoiding mistakes.

One of the basic elements of the education and training of public administration employees is (or at least should be) the conscious and direct development of their oral and written skills. ${ }^{33}$ There is obviously a need for controlled interactivity and for basic competences on both sides (students and trainers). ${ }^{34}$ According to our point of view, the concept of public administration and literature is one of the most usefully targeted forms of this interaction. ${ }^{35}$

7. In addition to the practical considerations - related to communication - there are more general arguments related to the conscious renewal of the Hungarian legal-administrative language. Any training that focuses on the questions of language cultivation in its narrower sense, can also contribute to the conscious development of the given specialized vocabulary. ${ }^{36}$

The Hungarian state administration language was created during the language reform that took place in Hungary in the Reform Era. Its special suffixes (some of them still used), as well as its overly complicated sentence and phrases, its curious circulars were salient even in those days. ${ }^{37}$ Dezső Kosztolányi's movement for the cultivation of the mother tongue in the early $20^{\text {th }}$ century fights against, among other things, the excessively legal character of this language register (the so-called wooden language [bikkfa-nyelv]).

The oldest commonality of official language cultivation is the legal language; today, in particular, the interpretation of various kinds of loan words and loan translations, such as the interpretation of certain phenomena characteristic to the EU language use, and the action against Anglicisms have come to the fore. The most obvious problems include the fact that citizens do not understand, or do not properly understand laws or forms, etc., a reason of which, among others, is the fact that the administrative language (specialized vocabulary of law and administration) is strongly characterized by the lack of preverbs and the use of some specific preverbs in a manner that contravenes the rules of standard language use. Similarly, it is typical that mistaken practice uses phrases compound of a meaningless verb linked to a noun; for example, to exercise control, to take an action in sentences where the simpler and more accurate verbs to control and to act would be more suitable. ${ }^{38}$

It is essential that the introduction and dissemination of a unified terminology or the simplification of legal and official texts, the clarification of their content in order to make them customer friendly are tasks that are not possible solely through workshops of the employees of the sectoral ministry; these efforts need to be given a wider range of impulses by a wider circle of participants who - through debates - may reach the best solutions. ${ }^{39}$

8. The need for more conscious appearance of pedagogy and didactics in legal education. In today's most widely accepted approach to pedagogy, teaching is primarily to promote the acquisition of socially relevant cultural content, to develop the skills and the abilities to perform certain operations, to develop basic and special competences, to educate for a cultivated behaviour, to have an appropriate attitude in society (tolerance, cooperation, 
empathy)..$^{40}$ This definition is also suitable for describing the goals of the transfer of legal/ administrative knowledge, with the remark that today's teaching is strongly lopsided; the systematic transfer of professional dogmatics-based knowledge has become the focus point of the aspirations, to the detriment of the development of human qualities and of the general training of future intellectuals (as possible functions) (see earlier). In the Middle Ages, the methods used in scholasticism are applied to universities: the presentation of the theses to be proved, the listing of arguments, and of the counter-arguments, the detailed presentation of the theses and the denial of the counter-arguments. The terminology of didactics was introduced by Comenius, father of didactics, in his work entitled Didactica Magna. In his work presenting new approaches, he suggests that things be presented through sensuous, experiential, intelligent, self-reflective considerations. His emphasis on authoritarianism is under burden, but he does not stop at the level of empirical knowledge, as he considers that the senses cannot by themselves lead to the knowledge of the essence of things, though their use is inevitable in the process of cognition. The theoretical concept of didactics, in addition to the intellectual elements, is as well built on emotions. ${ }^{41}$

What should a child learn? - the old question is formulated. According to Fináczy a child should learn that he/she is interested in by his/her natural desire for knowledge: "The main driver of a child when learning is the instinctive curiosity for the things that are unknown to him/her in the outside world." ${ }^{42}$ Rousseau in his work entitled Emil, or Education, referring to this curiosity, warns educators, too: "While feeding the child's curiosity, never hurry to fully satisfy it. Offer him/her the question and permit them to solve it by themselves." ${ }^{33}$ Ready-made knowledge - according to Rousseau - is not worth much: "the child should not learn the science but find it." ${ }^{\prime 4}$ In the (law and literature), (public administration and literature) courses, one of the most exciting tasks for students is the reconstruction of the story and novel events. In the current system of legal/administrative education, which focuses essentially on the acquisition and dogmatic analysis of rules, the students rarely encounter the task of fact finding. Even in those law courses where court decisions are being analysed, students have to deal with already prefixed legal facts that highlight the most relevant elements of the case, so the difficulties and pitfalls of the fact-finding itself have remain unknown for the students. ${ }^{45}$

The relationship between law and literature (public administration and literature) is a lucky match for all those who want to renew the didactic features of legal/administrative education. ${ }^{46}$ It is indeed lucky because, with some exaggeration, many of the negative tendencies in today's legal/administrative education can be handled well and can be controlled by using this method in a deliberate and planned manner. The most disturbing features of higher education in the domain of legal studies in our days - such as the lack of integrity, the rapid decline in the level of general literacy, the lack of interest, the lack of career and vision, the lack of mutual respect in the relationship between teacher and student respectively between students - can be well compensated by a legal/administrative higher education that builds on the relationship between law and literature. It should be emphasized that although higher education has a certain internal logic and framework elaborated centuries ago, one of the decisive reasons behind the alienation of students is the presence of Prussian-type teaching methods and environmental elements that remained unchanged in education. In this context, any method that really contributes to the 
development of a pleasant environment and helps the free expression of opinions can become a real breakthrough in higher education. In this endeavour, increasing the number of practical courses and the forcing of seminarization cannot, in itself, lead to breakthrough results. The introduction of additional stimulating elements is also necessary, such as creating and offering an aha experience as a result of personal reading experiences; the atmosphere reminding of exams being delayed - at least for the seminar and, perhaps the most prominent element: presenting moral dilemmas as a perspective for the future socialisation of students in the world of legal practitioners, and at the same time as a tool for enhancing the career image and enhancing self-confidence.

Thus, according to the didactic-methodological approach, new forms of indirect transfer of knowledge should also be introduced in the process of education (e.g. through reading together literary works that deal with issues of public administration, describing, interpreting, analysing and adapting these works). These indirect methods play a particularly important role in dictatorships, since the only possibility for free interpretation of reality is art, but these methods may also be useful in a democratic social structure for the perception of processes, and for the understanding of the real weight and value of the social phenomena.

The connection between the two areas (administration and fiction) is, of course, not recent. There are also works that use fiction as an excuse to present the author's administrative, organizational and leadership theories or political ideas. A good example of the latter is Balzac's novel, ${ }^{47}$ The Government Clerks, that is the carefully elaborated, detailed, administrative reform plan of the author aiming to reduce bureaucracy.

It is also necessary to highlight the civilizational fact that until the first third of the twentieth century legal-administrative literacy was not primarily a labour-market factor in the public sector and society; it was rather intended to signify the belonging to the respective political elite and ruling class, and its intention. For a nobleman or a civilian who respected himself, the opportunity to access higher education and to obtain theoretical education in the field of law or theology was precisely the consequence of his social status. It is important, however, to emphasize that this knowledge was in many cases more widespread than good; the social status and the relations, the general culture and the language skills of the public administration staff and state apparatus (German, Latin, French, minority languages) in most cases proved to be enough, especially when it was supplemented with the practical knowledge acquired with each case. However, as society became more complex, administrative and other legal activities had become more and more complex, as well and required more ${ }^{48}$ specialized expertise from those working in different administrative areas.

\section{The Possible Relations Between Public Administration and Literature}

According to the simplest - and perhaps the most commonly used - scheme (see Chapter 2) in this research area there can be distinguished two distinct basic approaches: one that analyses how law appears in literature and the other one that considers the law itself 
a particular literary genre (law as literature). ${ }^{49}$ This latter may become the subject of literary analysis. ${ }^{50}$ As a result, we may state that a differentiation must be made between public administration that appears in literary works and administrative law as a literary performance. This study - for practical reasons - uses the former approach to explore the criteria and the exemplified arguments suitable for group-formation that will allow the scientific examination of this area and will make progress in the field possible.

\subsection{Law in Literature, Public Administration in Literature}

In the relationship between law and literature (public administration and fiction), it is an essential question how close the legal motive is to the literary frame and genre? To what extent is the existence of a kind of symbiotic relationship important/necessary for the presentation of these aspects as a meaningful, contextual opportunity for interpretation? We instinctively give the answer that the legal/administrative problem appearing in the literary work should be expressed and more or less well-defined and the character of the depicted figure should have sufficiently sharp contours. This means that the presence of the law or of a legal practitioner/of the administrative phenomenon or of an administrative expert in the literary work is some sort of a guiding motif, or at least must be strongly emphasized in the work.

The vast majority of law and literary courses offered in higher education in law, follow the method presented by Anna Kiss. Everyone chooses a literary work, a novel, a poem, a short story or a drama and analyses it from a legal point of view; the end-of-semester evaluation is mainly based on this work. ${ }^{51}$ Obviously, the interpretation of works that deal with administrative problems (that can be regarded narrower or wider than the legal subject matter) is made in a similar way.

The path leading to the correct interpretation of literary works is generally suggested to go through - not just in the context of law and literature/public administration and literature - three stages: contextualization, de-contextualization, and finally through recontextualization. Contextualization is the intellectual effort to discover the meaning of the work in the light of the circumstances of its creation. This includes the discovery of the author's relationship with literary traditions and social problems of the age, as well as the presentation of the work's place in the author's oeuvre and the highlighting of the literary themes and aesthetic issues the author was interested in. In short, contextualization aims to outline the author's intentions, or at least to draw the horizon of acceptable interpretations, which, of course, include a multitude of possible interpretations, since the author's intention can never be clarified precisely. In the second phase of the interpretation, that is the stage of de-contextualization, we concentrate our attention on the work itself, as an aesthetic and intellectual whole, thus extracting it from the context of its creation. For a novel, this traditionally includes, for example, an explanation of the plot, of the characters and of the roles played by the characters; of the relationship between the narrator and the characters, and of the dramaturgical structure of the work. The very purpose of our investigations is to bring to surface the meaning hidden in the work, irrespective of the original intent of the author. Finally, the re-contextualization of the literary work seeks to 
define those aspects of the current literary tradition and of social conditions, that can be used to delimit the variations of the meaning of a literary work perceived by us and - as a consequence - at the same time we can find a basis for our aesthetic values. ${ }^{52}$ The most definitive "[d]idactic result of the contextual interpretation may be the amplification of the students' emotional vibrations existing in the contradiction between reality and imagination, identification and critical distancing, which is not merely the basis of legal profession and literature, but it gives the basic tone of the creative human life in general, too".53

If we try to make order in the domain of public administration and fiction - thus also helping towards a more and more conscious use of this method in the areas of legal/ administrative education - we need to find the right categorization criteria that can be used to catalogue the dispersed and possibly displayed elements of the existing relationship in literature so far. In this study we will use three major approaches for the purpose of categorization: ${ }^{54} 1$. firstly, the administrative background and activity of the author of the literary work; 2. secondly, the literary genres used to represent the administrative theme; 3. and thirdly, I classify the otherwise available (collected) works according to the upcoming administrative themes (problems).

\subsubsection{The administrative background of the author of the literary work}

There are some authors for whom we cannot draw far-reaching conclusions from the fact that they attended law school or studied law when they used to be university students, or later they worked in public administration; in their works, the legal/administrative themes are often absent or only very indirectly present. This group includes Georg Philipp Friedrich von Hardenberg, also known as Novalis, who first had studied law at the University of Jena and then at Wittenberg, and later used his knowledge in the mining industry. ${ }^{55}$ In spite of this biographic fact, his work entitled Heinrich von Ofterdingen does not deal with the law, the world of law or the mining administration.

Looking for Hungarian (counter) examples: János Arany - one of the greatest writers of our literature who worked both as deputy notary and as public servant in the Ministry of the Interior and was for a shorter period of time employed in the Hungarian public administration, in his works often recalls neighbourly disputes, and other similar legal problems.

Perhaps neither would have Péter Esterházy become who he had become if he didn't work as an employee of the ministry, ${ }^{56}$ because the experience gained there obviously helped him in creating a new literary language promoting the legal-administrative wooden language and "interpreting the medium of this linguistic register". ${ }^{57}$ The language form used by Esterházy in his novel entitled Termelési-regény [Novel of Production] is the result of conscious choice of style; the author could not have found a more suitable tool for describing and displaying this hard, brittle and in many ways opaque world.

As far as the staff of today's Hungarian public administration is concerned (in this respect, not including public servants, teachers, university lecturers), there are not many spectacular literary performances combined with an intensive participation, and even the existing works belong almost exclusively to the category of poems and short stories. 
Of course, our aim cannot be a subtle evaluation of particular performances or of some kind of total performance, but it must be noted that the visibility of literary forums, workshops and experiments generated by the wider public sector or even within the public sector is low.

\subsubsection{The literary genres used to represent the administrative theme}

1. The first appearance of the subject under review is bound to the genre of drama. In Antigone of Sophocles, which is the third most frequently used dramatic work in the Law and Literature courses, after William Shakespeare's Measure for Measure and The Merchant of Venice, Antigone and Kreon are examples of self-righteousness and legal thinking, as opposed to the figures of Ismene and Haemon. Both Kreon and Antigone take in consideration only a particular sphere of values - for Kreon the city's prosperity, while for Antigone the family's unwritten rules are the only important issues, and both ignore the values represented by the other. Of course, the diversity of viewpoints and interpretations can be explained by the opinion of George Steiner, who distinguished the five fundamental conflicts of human life that can be the basis of a dramatic confrontation: man and woman, elderly and young, society and individual, living and dead, and the conflict between humans and gods. According to Steiner, Antigone is one of the few dramatic works in which all five conflicts appear. ${ }^{58}$

One of the peculiarities of public administration, particularly in dictatorial circumstances, is that the regime wants to encroach in the relationships of each of the above mentioned opposition pairs. Often in the literary representations of administrative systems having basically democratic structure, the focus is on the erroneous methods of solving these basic conflicts thus criticizing the wrong and unreasonable appraisal of the law, the content of the defective legislative instruments, or the attitude of the public servant who represents the lawful but inhumane procedures, sometimes without any consequences.

2. Among genres, perhaps the novel is best suited to present a request, an application, or an official decision in its integrity, without damaging the content of the text. Woolf has a very particular approach towards the novel: "The novel, and I think art in general, wants to capture our vision of life in its intense and intact entirety and not in its components, or interpreted aspects." ${ }^{59}$ This totality of epical tools is the motive for which law cannot lack literature; the institutions and texts of the law are so far from the most subtle contents of the notion of life, that it is worth using the mediating and interpretative role of literature that can offer solutions to understand the context of law. In our days, law in many respects is like a modern novel, which is restricted to the presentation of the story or of the events without any emotions - and in this case this is a negative criticism - from which, in Virginia Woolf's opinion, "life disappeared and evaporated like camphor".

Similar issues are discussed by Peter Brooks, who examines the act of confession in the light of law, literature, and psychology and concludes that the law is incapable of providing the "fearless story telling". ${ }^{60}$ The latter reason is the one that almost compels the literary frame, thereby promoting the linkage of law with life. ${ }^{61}$ 
Today's universal literature gives a number of examples, which cannot be all listed here, dealing with the administrative theme. Perhaps it is not coincidental, that the first novel of the most well-known authoress of our time addressed to adults, also presents an administrative problem. J. K. Rowling's The Casual Vacancy is a novel about the process and the background of filling a vacant seat in the council. In the shadow of the elections peppered with passion, tergiversation and astonishing blasts, Rowling draws the portraits of social workers and the local teachers in an extraordinarily living way. The plot follows several threads of action and gives a rather complex picture of not only the wider public life of the small town, but also the narrower public administration and its social environment.

Hungarian fiction, especially in the $19^{\text {th }}$ and early $20^{\text {th }}$ centuries, gives many examples of the faulty, sometimes humorous functioning of the public administration and of the executive power, highlighting at the same time difficult moral dilemmas, as we can see in Jókai's or Mikszáth's works. The newer Hungarian novel - similarly to international trends - often uses topics of secret services and police investigations. Under the pseudonym David J. Doesser, Dr. János Nagy, a former intelligence officer from the Information Office, published in 2012 at the Athena Press in London the book entitled $A$ Very Important Message which is a memoir based on real events, disguised as a novel. The book is mostly based on events taking place in Hungary, and the focus of the novel is on the intelligence service of the Socialist Age, called III/I and its successor organization, the Information Office. An interesting thing related to the book - due to its author - is that Nagy, at the time of the first Orbán Government, was removed from the Office for espionage on behalf of the CIA.

Within the genre of the novel, a rarely used form is the verse novel. The most popular piece of the examined field is János Térey's Protokoll. Regény versekben [Protocol. A Verse Novel].62 The protagonist of the novel, Ágoston Mátrai, the Chief of Protocols of the Hungarian Ministry of Foreign Affairs, leaves behind a Scotian dinner and drives to the beach. He is sitting alone in the middle of the deserted northern landscape and takes account of his life: "There is no way of doing anything, and this makes me sad. / What we had been left, will be handed on by us: the rituals are transmitted. / Help everybody, solve everything? / Our show: a symptomatic treatment." This resigning recognition is quite different from the life-wisdom that Mátrai formulates at the beginning of the volume: "You are my god, Frosty Protocoll! And you are my gods, you all, / Ordinary / mutually agreed / norms! If you don't exist any more / the unfold jungle will suffocate us." While this opinion considers protocol a culture-conscious, meaningful and civilizational activity, the former regards it as a substitute activity that, in most cases, is just an afterthought. There is apparently a great distance between these two opinions, and this is the journey that the hero of the Protocol is taking on the pages of the novel. ${ }^{63}$

One of the strengths of the novel is that it illustrates the inseparability of politics and public administration, and it also provides an accurate insight into this domain.

3. The genre of the short story is also a common framework and instrument for representing legal events and cases and characterizing administrative/legal professionals: Anton Pavlovich Chekhov's short story entitled The Death of a Government Clerk represented in those days the renewal of the genre. When reviewing the Hungarian examples, we also perceive the dominance of, or at least the emphasis, of police activity as 
a theme in this genre. In the earlier Hungarian literature Kálmán Mikszáth's short story entitled Egy rendörzseni [A Genius Policeman] and in the present days Krisztina Lamos' work entitled Késésben [Being Late] are good examples of the genre. ${ }^{64}$

4. In addition to the dramatic and epic genres, of course, we cannot forget poetry, which also has lots of special instruments like: intense depiction of reality, ${ }^{65}$ humorous and at the same time revealing rhymes, epigram-like compactness, mysterious atmosphere of ballads - all of these contributing to the presentation of problems reaching almost philosophical altitudes related to the life of the community and ${ }^{66}$ to the representation of the depths and disadvantages of law-making. Among the numerous examples here is Miklós Radnóti's two lines from one of his poems that is a masterful example of the genre being a tribute to a lawyer. The poem is entitled Tünemény [Phenomenon]: ${ }^{67}$

Couldn't it have become a law for itself,

so many smaller rules came to force to help.

\subsubsection{At the border of fiction}

Beside the most traditional genres, there are also combined genres, as follows:

1. The traditional form of displaying science accessible to the public is the genre of study and that of the essay. ${ }^{68}$ One of their characteristics is that they often use literary tools in the processing of their subject, and they (also) strive for literary influence. It would be a mistake to hide the fact that both the study and the essay have changed dramatically with the rise of the electronic media. Indeed, not only the forms of speaking about the law/public administration, but also the way in which the legal and administrative sphere is operated had been fundamentally changed by the fact that legislative processes and individual decisions are not merely subjects of debate for a narrower circle (as it is conceived in its traditional sense), but also for the broader popular public, and consequently the media speaks about them as its own. ${ }^{69}$ One of the peculiarities of the new law life that dissolves in the knowledge about law/public administration is that the otherwise complicated subjects of law are aimed to be presented to the reader with eloquent simplifications renewed and developed day by day. We do not even have to look for faraway cases: the writings concerned with the tax system appear on various websites on hundreds of pages.

2. Another genre being at the border of fiction is the biography, which itself as a genre belongs to the essay literature, if its purpose is not (primarily) the scientific research and communication of data but the portraying of the human character, which always requires a kind of artistic imagination. ${ }^{70}$ Because of the very stylistic nature of the biography, it necessarily shows literary values in the presentation of a lifeway and of its carrier. These kinds of writings differ from scientific rendering of facts, due to the fact that (auto) biographies having lots of biographical data become a special journal, a work that presents life to the reader, the opinions and the worldview of the protagonist of the biography (both in case of a real self-written journal, and in case of journals having external authors).

3. Another genre related to the former is the interview-volume consisting of edited conversations, many examples of this genre being available in Hungarian literature. Here we 
can mention the volume based on a long series of conversations with the well-known lawyer, Dr. György Bárándy. ${ }^{71}$

In Hungary, there is a tradition to publish volumes of interviews and biography-like writings with the current prime minister, and these books are not merely scientifically elaborated studies, or collections of newspaper articles, but they want to affect emotions, too. $^{72}$

4. In addition to interview volumes of prime ministers and ministers, as we have already mentioned, the world of secret services ${ }^{73}$ is constantly present in our broader literature with a genre related to the aforementioned genres, that is fact-finding and investigative (essay) literature, because there is demand for such books.

5. The systemic features of the legal-administrative sphere, the universal misery and limitations of the system, can be very well presented by certain genres such as humoresques and pamphlets - which are particularly suited for criticizing the law and the lawyer, revealing their plight in a moral sense, and, in all cases, this presentation is turned into sharp and ruthless criticism - of the society. Mark Twain's pamphlet, Running for Governor (in fact, a short story) is an excellent example of a literary representation that reveals with meticulous accuracy the scandalous reality behind a satirically exaggerated sloppy jumble, which on the one hand justifies the purpose of selfish means in legal procedures and on the other hand it laughs at its ineffectiveness. During the presentation of different forms of the death of law, the writer is in a state of difficulty, as he presents a problem the professional characteristics and legal delicacies of which are not or are hardly accessible to a significant part of his readers. In this case, the most obvious solution is to increase the malaise, pumping it into a giant balloon, and then make it spectacularly ridiculous.

6. We cannot forget about some of the transient or mixed genres either - that specifically deal with the subject of public administration. An example of this is the pamphlet-like writing, which essentially mixes the features of the scholarly studies and of the essays, among which the most well-known is C. Northcote Parkinson's volume entitled Parkinson's Law: The Pursuit of Progress, ${ }^{74}$ a book that does not lack scientifically based arguments, is a sharp criticism of the bureaucratised public administration, and having an ironic tone in its every sentence, becomes a totally sarcastic review of public administration. According to Parkinson's calculations, based on mathematical formulas, there is a moderate increase in the number of officials on an average of $6 \%$ per year, regardless of the actual workload. That is, bureaucracy not only reproduces itself, but also expands and always has a decisive role to play in its continuous self-importance.

7. Moreover, we cannot forget the joke as a specific literary genre, as it is still a flourishing area that produces new crops every day, to present law and especially to portray the scumbag lawyer/civil servant. ${ }^{75}$ In the narrower domain of public administration, the largest number of jokes is about police officers, this type of joke is likely to occur on a daily basis in at least dozens of jokes in Hungary. ${ }^{76}$

We also encounter books that bring together jokes, short humorous stories (anecdotes [adomák]) from several public areas. One of the most popular such volume is the book entitled Mosolygó közigazgatás [Smiley Public Administration] by József Pogány published before World War II. "Where does the humour of dry formal life generally come from?"Pogány asks, then he answers: "First of all, from the degeneration of the so-called 
bureaucracy, secondly, from the discrepancies between regulations and their implementation, that appear in the very moment when the statutory provisions face the individual. When private life is limited by regulations, people respond by mocking the situation. People would like to survive regulations, so either they try to ignore them or if this is not possible, they - while suffering from their absurdity - make jokes of them. But most of all, the humour of public administration, appears when simple-minded people, lacking any education for official life, gain the right of action (policemen, criers, coroners). It is no wonder, that while they do their work with serious obedience, in their actions or writings humour appears by itself."

In conclusion, besides acknowledging the primacy of the novel - we can conclude that there is hardly any literary genre that would not be suitable for displaying certain administrative topics; indeed, because of the characteristics of each genre, certain themes may appear more comfortably and sometimes even more appealing in frameworks dictated by certain representation forms.

\subsubsection{The possibility of categorizing according to processed topics}

Due to the diversity of possible topics, I would like to point out only examples in this section; I do not aspire to completeness nor do I want the categories that I describe to be homogeneous. This latter aspect also means that works in a certain category are in many cases matched to successive categories; some novels would stand in almost all categories...

It can be seen that authors and writers of different nations often run along welldefined themes while creating their works. The significance of historical, geographical, cultural and other determinations cannot be overestimated. Obviously, in the works of Heinrich Böll, many of the moral and thus legal conflicts of German society after World War II appear, and consequently, many aspects of the problematics "I did it for it was an order", emerge. In case of Böll, the great value of the literary gown is that he illustrates not only the peculiarities of defence administration by presenting in an objective manner without any emotions, banal cases like the stealing of butter by mess officers, ${ }^{78}$ or more serious cases of war crimes, but he also outlines the circumstances, motivations and other legally relevant facts that should otherwise be explored in any case. "Oh God, I have often wondered what a terrible power must it be the force that can deprive millions and millions of their will, and can force them to face death - even if they are cowards or frightened - as we have done it in that night." $"$ 9

If we were to find out on the basis of our literary works what areas and aspects of the Hungarian public administration were in the focus in our post-regime society - assuming that fiction is the imprint of what is really important in the given era - the outlines of some areas could be well perceived. Obviously, the privatization or the appearance of the banking world were among the most important topics. These topics, which can be treated as important elements of economic and political transition, have provided many administrative contexts that appear in reference works sometimes with a documentary character. Gábor Lenkei's novel entitled Vegyünk bankot! [Let's Buy a Bank!], ${ }^{80}$ the main character of which is Péter Ovács, a young lawyer, presents the tragicomedy of privatization in 
the 1990s in Hungary. In the story, the state-owned bank financed its own sale, and Ovács with his formerly fired friend from the bank received the cash for the disbursement from the bank. The semblance of legality is maintained all over the story, so the ending of the novel is not at all suspenseful. However, in P. G. Woodehouse's style, the author puts a curved mirror in front of all the actors of the process: the buyer (Ovács who seems to be the successor to Psmith), the bank itself and the state officials who let this transaction take place in such a form.

During the privatization process, not only Gábor Lenkei was encouraged to write, but others like István Kerékgyártó also tried to reveal a segment of the life of Hungary between 1989 and 1997. His book, Vagyonregény - Ipszilon történet [The Book of Riches - the Y-story ${ }^{81}$ is a diary with personal reflections and sociological-political commentaries, the entries being written by two women, responding to each other's thoughts. The story with surprising methods, however, responds to the state of the public at that time, most of the journal entries correspond to real events, so the novel becomes a picture of the society.

Of course, the relationship between public administration and fiction can be explored not only according to the particular area of administration, but also taking as a basis the characteristics of public servants. The applier of the ruthless law reverts to being a human through literary means, and will become a sentient creature for whom it is difficult to express the feelings and desires otherwise important for him.

In the significant part of these works it is not revealed (because it is not particularly important for the message), ${ }^{82}$ whether the public servants, the clerks or the officials have any legal studies or they act on birth right, or based on a diploma obtained after graduating a simple course. Not only do we experience in practice that relationships, habit and skills often blur for a certain person the conditions otherwise necessary to fill a particular job; in literature, these details appear to be of even lesser importance because they are not so relevant for the transmission of the message.

In the Hungarian literature we see that earlier, the actors of the local and regional public administration dominated the market. This is well illustrated by books like $A$ falu jegyzője [The Village Notary] by József Eötvös or Egy falusi nótáriusnak budai utazása ${ }^{83}$ [The Village Notary's Journey to Buda] by József Gvadányi. The Village Notary is the most famous novel of József Eötvös being the first really important intent to give a cross section of the entire society. The novel sets objectives similar to those of Balzac's work. ${ }^{84}$ In the novel, we get acquainted with a Hungarian county in the Reform Era with its whole staff and poor people, political struggles and everyday life together with the typical forms and locations of county life. Macskaházy who is the lawyer of the sub-prefect's wife, helps her steal the patent of nobility of Tengelyi Jónás, the village notary, together with some materials and documents uncomfortable for the lady, thus stopping the clerk from running at the local elections. ${ }^{85}$

Jókai's work, entitled $A$ régi jó táblabirák [The Good Old County Judges] deals with a topic related to local-territorial administration. ${ }^{86}$ In his work he raises questions as whether public interest may be subject to private ownership; or more precisely: can the bungry, floodprone mass be satisfied from the provisions storehouse of the landlord?

The basic question is the same in Zsigmond Móricz's novel entitled Rokonok [Relatives]. In the last great Móricz novel, the hero, István Kopjáss, is a young member of 
the gentry who is superior to the average and aims high, using his talent. As a simple cultural consultant, he still has great plans and dreams, but as soon as he becomes the prosecutor of Zsarátnok (a small Hungarian town), he soon begins to deny his principles, and is absorbed by the world of the Panamas, and he only cares about his own career. By the time he finds out the cruel truth, there is no moral ground for him to mend the situation and he commits suicide... The Relatives illustrates that those who make a series of compromises will lose their most precious features and will be just like the born villains.

The latest Hungarian literature - compared to the above quoted works - is attracted mainly to the institutions and actors of the central administration. What exactly is in the background of this attraction, cannot be exactly known, although it may be suspected that nowadays the everyday life of a ministry is even more accessible for the writers. Among the reasons we may include the fact that the literary elite is also in contact with representatives of this sphere, for example, when participating on official dinners, receptions or other social events.

László András in his novel ${ }^{87}$ entitled Egy medvekutató feljegyzései [Notes of a Bear Researcher] presents with means of literary parody the start of a career in the ministry. Zsolt Koppány Nagy's novel entitled Nem kell vala megvénülnöd 2.0 [You Shouldn't Have Grown Old 2.0] creates a grotesque world with vitrioliously ${ }^{88}$ humorous and vigorous precision, a world that is very similar to our present. János Fényező Nagyjuhász, a civil servant growing old and hungry for love, lives his everyday life in the Department for Salt and other Brining Materials that is muggy with intrigues. In the negative utopia of Zsolt Koppány Nagy, the older civil servants are liquidated, so the protagonist can do nothing but flee and think about his life... Counter to the work of László András (in which we meet the hero at the beginning of his career) Nagy presents the emotional, psychological and physical tribulations of leaving office for good.

The ministry and the life of a ministerial employee - being an ideal subject of a novel - are recalled in other places, too: the above mentioned verse novel written by Térey takes the reader into this world.

Additionally, one of the most commonly used legal-administrative roles in a literary work is that of the employee dealing with law enforcement - sometimes called a judge, sometimes having another function (e.g. a civil servant deciding on neighbouring issues, etc.): as the notion of a county judge for instance is not valid any more, it should be replaced under the present conditions with another role having an essentially administrative character. A judge sometimes is an oracle, a real hero, but sometimes a person having surprisingly human features: "Who was the one who could administer public affairs with wisdom and honour - but little money? The good old county judges. Who excelled in theology, science and morality? The good old county judges." 


\section{References}

1 Tamás Nagy, Jog, irodalom, intertextualitás [Law, Literature, Intertextuality], 39, in Péter Takács (ed.), Ratio Legis - Ratio Iuris. Ünnepi tanulmányok Tamás András tiszteletére 70. születésnapja alkalmából [Ratio Legis - Ratio Iuris. Festive studies in honour of András Tamás on his $70^{\text {th }}$ birthday] (Budapest, Szent István Társulat, 2011).

2 That is, if we approach from the perspective of literature, either the legal-administrative theme (issue of law, codification problem, etc.) appears directly in fiction, or the legal language used in a literary oeuvre becomes the subject of the research. As a third possibility: the indirect effect of legal texts on the process of literary creation might become demonstrable. From the point of view of law (science of law), the question arises: what was the role played by the literary works of the age, by the political, social criticism of the particular era, etc. and by some quasi-literary works, for example, the Bible, in the formation of legal texts, and that of language use, new terminologies, and so on.

3 Tibor Kalas, András Torma, Közigazgatási jog I. Magyar közigazgatási jog. Általános rész [Administrative Law I. Hungarian Administrative Law. General part], 65 (Miskolc, Virtuóz Kiadó, 2007).

4 András Tamás, Közigazgatási jogtudomány [The Science of Administrative Law], 67-68, in Marianna Fazekas (ed.), A közigazgatás tudományos vizsgálata egykor és ma. 80 éve jött létre a budapesti jogi karon a Magyar Közigazgatástudományi Intézet [A Scientific Examination of Public Administration Once and Today. The Hungarian Institute for Public Administration was established at the Faculty of Law in Budapest 80 years ago] (Budapest, Gondolat Kiadó, 2011).

5 András Sajó, Társadalmi-jogi változás [Social and Legal Change], 7 (Budapest, Akadémiai Kiadó, 1988).

6 See e.g.: György Szerbhorváth, Who's the Star of the Show? On the Advantages and Disadvantages of and the Relationships between Sociography, Sociology and Literature, 100-112, in Intersections. East European Journal of Society and Politics, vol. 1, no. 2 (2015). https://doi.org/10.17356/ieejsp.v1i2.113

7 For details see: István H. Szilágyi, Jog és irodalom (habilitációs előadás) [Law and Literature (Habilitation Thesis)], 5, in Iustum Aequum Salutare, vol. 6, no. 1 (2010); Nagy, supra n. 2, at 38-47; and respectively Anna Kiss, Henriett Kiss, J. Zoltán Tóth (eds.), Escapade or sin? 7 (Budapest, Complex Kiadó, 2010).

8 Szilágyi, supra n. 8, at 6.

9 Empirical sociology, the actual sociography, came into being at the beginning of the $20^{\text {th }}$ century, its current mission being the description and characterization of all conditions and status of a community in a particular age using every possible tool and device. As Bartha points out, "emphasis is on 'every tool and device, which opens a wider spectrum to the practitioners of the genre compared to those available for scientific sociology. The arena was extending from statistics to economics, from geography to pedagogy, from politics to literature that was theoretically gaining its independence at the time when sociology was born, and it was used by our sociographers profoundly in the discussed period. Paradoxically [...] the complexity of sociology was the most elaborated in Eastern and Central Europe". Ákos Bartha, Szaktudomány vagy szépirodalom? Szociográfia a Horthy-korszakban [Science or Fiction? Sociography in the Horthy Era], 54, in Debreceni Disputa: kulturális-közéleti folyóirat, vol. 14, no. 4 (2010).

10 Szilágyi, supra n. 8, at 14-15.

11 Rebecca A. Hill, Law and Order in Science Fiction, 42-43, in Voice of Youth Advocates, vol. 6, no. 4 (2015).

12 See for example: J. Zoltán Tóth, A ,jog és irodalom” felhasználása az egyetemi oktatásban [Using “Law and Literature” in University Education], 231, in Balázs Fekete, István H. Szilágyi, Tamás Nagy (eds.), Iustitia mesél, tanulmányok a jog és irodalom köréböl [Iustitia, the Storyteller: Studies from Law and Literature] (Budapest, Szent István Társulat, 2013).

13 Balázs Fekete, A jog mindenkié? A jog emberképének belsö feszültségeiröl irodalmi hösök segitségével [Does Law Belong to Everybody? About the Inner Tensions of the Conception of Man as Reflected in Law through Literary Heroes], V. Jog és Irodalom szimpózium [5th Law and Literature Symphosium], 2014. május 15-16. Előadások rezüméje. [15-16 May 2014. Synthesis of the presentations], 8 (Budapest, PPKE JÁK, 2014). 
14 Tamás Nagy, Jog és irodalom [Law and literature], PhD thesis, manuscript (Szeged, SZTE ÁJK, 2006); and Ádám Rixer, Jog és szépirodalom [Law and Fine Literature], 165-194, in Iustum Aequum Salutare, vol. 8, no. 2 (2012).

15 András Jakab, A magyar jogi oktatás megújításához szükséges lépések - Reformjavaslat összehasonlító áttekintésre alapozva [The Steps Required to Renew the Hungarian Legal Education - Reform Proposal Based on a Comparative Overview], 201, in Magyar Jog, vol. 57, no. 1 (2010).

16 Béla Pokol, A professzionális intézményrendszerek elmélete [The Theory of Professional Institution Systems], 218 (Budapest, Felsőoktatási Koordinációs Iroda, 1992).

17 Jakab, supra n. 16, at 204.

18 See: Ádám Rixer, Megjegyzések Jakab András jogi oktatásra vonatkozó reformjavaslatához [Comments on András Jakab's Reform Proposal of Legal Education], 545-551, in Magyar Jog, vol. 57, no. 9 (2010).

19 Iwona Sobis, Michael S. de Vries, Restoring Professionalism: What Can Public Administration Learn from Social Psychology? 95, in Juraj Nemec, B. Guy Peters (eds.), State and Administration in a Changing World (Bratislava, NISPACee, 2010).

20 Ibid. 97.

21 Ibid. 104-107.

22 Ádám Rixer, A roma érdekek megjelenitése a jogalkotásban [Roma Interests in Legislation], 178-182 (Budapest, Patrocinium, 2013).

23 Zsolt Péter, A magyar közszolgálati „Etika és integritás”, valamint az „Integritásmenedzsment” tréningek hatásvizsgálata [Impact Assessment of the Hungarian Public Service Trainings: "Ethics and Integrity" and "Integrity Management"], 150-166, in Pro Publico Bono - Magyar Közigazgatás, vol. 3, no. 1 (2015).

24 Éva Ancsel, Etikai tanulmány a tudásról és a nem-tudásról [Ethical Study on Knowledge and Nonknowledge], 47 (Budapest, Kossuth Kiadó, 1986).

25 Ibid.

26 Marcell Benedek, Az olvasás müvészete [The Art of Reading], 7 (Budapest, Bibliotheca, 1957).

27 For more details see: István H. Szilágyi, Jog - Irodalom [Law - Literature], 94 (Szeged, SZTE ÁJK Összehasonlító Jogi Intézet, 2010).

28 In detail: Richard H. Weisberg, Poethics and Other Strategies of Law and Literature (Columbia University Press, 1992).

29 See also Balázs Fekete, Practice Elements in the Hungarian Legal Education System, 67-68, in Acta Juridica Hungarica, vol. 51, no. 1 (2010). https://doi.org/10.1556/AJur.51.2010.1.4

30 The legal framework in Hungary for the training in the domain of public administration, among others, are Act CXCIX of 2011 on Civil Servants and Government Decree no. 273/2012 (IX. 28.) on the Continuous Professional Training of Civil Servants.

31 Péter Princzinger, László Kisfaludy, $A$,jó állam” alapköve: a közszolgálati továbbképzés rendszere [The Cornerstone of the "Good State": The System of Public Servants' Training], 143, in Pro Publico Bono - Magyar Közigazgatás, vol. 3, no. 1 (2015).

32 Benedek, supra $n$. 27, at 8-9.

33 Brian A. Ellison, Teaching Writing in Public Administration Education, 25-31, in Teaching Public Administration, vol. 30, no. 1 (2006). https://doi.org/10.1177/014473940602600103

34 Miron Mushkat, Teaching Case Analysis to Public Managers in Academic Settings, 37-45, in Teaching Public Administration, vol. 25, no. 1 (2001). https://doi.org/10.1177/014473940102100104

35 Alistair McCulloch, Seeking the Holy Grail? Utopian Novels as an Aid to Teaching and Assessing the Political Analysis Component of Public Administration Courses, 73-78, in Teaching Public Administration, vol. 21, no. 1 (1997). https://doi.org/10.1177/014473949701700105

36 In detail: Ádám Rixer, A magyar nyelv és magyar jogi műnyelv megújulása. Vitaindító [The Renewal of the Hungarian Language and of the Hungarian Legal Language: Keynote], 9-15, in Glossa Iuridica, vol. 1, no. 1 (2014). 
37 Ferenc Gyergyák, László Kiss, Általános jogalkotási ismeretek. Tankönyv a köztisztviselök továbbképzéséhez [General Concepts of Legislation. A Textbook for Postgraduate Courses of Civil Servants], 100 (Budapest, KSzSzK KK, 2007).

38 Gyergyák, Kiss, supra n. 38, at 105.

39 Ibid. 102.

40 Iván Falus, Elméleti alapok a tanitás tanulásához [Theoretical Basis for Learning to Teach], 10 (Budapest, Nemzeti Tankönyvkiadó, 1998).

41 Ibid. 14-15.

42 Ernő Fináczy, Az újkori nevelés története [History of Modern Education], 123 (Budapest, Királyi Magyar Egyetemi Nyomda, 1927).

43 J.-J. Rousseau, Emil, avagy a nevelésröl [Emile, or On Education], 171 (Budapest, Tankönyvkiadó, 1957).

44 Ibid. 177.

45 Szilágyi, supra n. 28, at 151-152.

46 See e.g.: Zsolt Nagy, A jogi oktatás fejlódése és aktuális kérdései [The Development and Current Issues of Legal Education], 115 (Szeged, Pólay Elemér Alapítvány, 2007).

47 Honoré de Balzac, Hivatalnokok [The Government Clerks] (Budapest, Fapadoskonyv.hu, 2011).

48 As life became more complex, the subtle details, connections, had to be brought to the surface, and this was the mission of legal practitioners. Kálmán Kulcsár, Jogszociológia [Legal Sociology], 197 (Budapest, Kulturtrade, 1997).

49 Szilágyi, supra n. 8, at 5.

50 See: Zoltán Kulcsár-Szabó, Olvasás/politika: a „Paul de Man-ügy [Reading/Politics: The Paul De Man Case], 22-30, in Tiszatáj, vol. 68, no. 8 (2005).

51 Anna Kiss, Bünbe esett irodalmi hösök. Jog és irodalom [Literary Heroes Fallen in Sin. Law and Literature], 8, in Ügyvédvilág, vol. 17, no. 1 (2009), http://ugyvedvilag.hu/laparchivum.php?ref=143 (accessed 1 January 2014).

52 Szilágyi, supra n. 28, at 149-150.

53 Ibid. 177.

54 I have already made a proposal referring to this categorization: Rixer, supra n. 15, at 165-194.

55 Novalis, Heinrich von Ofterdingen, 193-194 (Budapest, Helikon, 1985).

56 In 1974 Péter Esterházy obtained a university diploma in Mathematics (the title of his BA thesis was Optimum binary search trees). As a university graduate he worked in the IT Institute of the Kohóés Gépipari Minisztérium until 1978.

57 Esterházy became famous due to his short novel entitled Novel of Production (1979), especially as a result of his innovative language solutions.

58 Szilágyi, supra n. 8, at 8 .

59 Géza Ottlik, Maugham Salvatore c. novellája [Maugham’s Short Story: Salvatore], 98, in Áron Tóbiás (ed.), Tarts Nyugatnak! [Keep West!] (Budapest, Arión Kiadó, 2007).

60 Szilágyi, supra n. 8, at 11.

61 For details see parts 3, 4 and 6 of subchapter 3.1.

62 János Térey, Protokoll. Regény versekben [Protocol. A Verse Novel] (Budapest, Magvető, 2010).

63 József Keresztesi, Beatrix Visy, Két birálat egy könyvröl [Two Reviews of a Book], www.holmi.org/2011/06/ keresztesi-jozsef-visy-beatrix-ket-biralat-egy-konyvrol-terey-janos-protokoll-regeny-versekben (accessed 20 July 2015).

64 Kálmán Mikszáth, Egy rendőrzseni [A Genius Policeman], 184-188, in Kálmán Mikszáth, Novellák, karcolatok [Short Stories, Sketches] (Budapest, Kortárs Könyvkiadó, 2011). E-book; and Krisztina M. Lamos, Késésben [Being Late] in A Gregorina-kanyar. Moral History pályázat legjobb irásai. [The Gregorina Twist. The best works of Moral History Competition] (Budapest, Xantusz könyv Kft., 2012). 
65 One of the most well-known Hungarian poems - the poem's aim is to present the willingness of people to start lawsuits, and the shrewdness of judges - is the Fülemile [The Nightingale], written by János Arany in 1854 , outlining a fictitious lawsuit in which the neighbours initiate a lawsuit, the object of which is a twoby-four case: one of them had planted a tree and some of its branches are above the courtyard of the other, the question being to which of them does the whistle of the bird sitting on the branch belong.

66 Endre Frady: Köz (Közérdekü közhelyek) [Cliches] (Budapest, Manuscript, 2014).

The man is searching for its place in the pack

In the meanwhile will he lose his stamp?

Is the community a pack if persons lack

Any sense of the pack?

Will the pack say to the person what to do?

Without taking its right to do?

Is the pack for all? Or all for the pack?

$\mathrm{ABC}$ : language or shop?

And what is the role of the Pack?

If I write about it will I be the sad sack?

Thanks pack, but no thanks.

67 Pál Réz (ed.), Radnóti Miklós összes versei és versforditásai [Miklós Radnóti’s Poems and Poem Translations], 296 (Budapest, Nagy Klasszikusok, Szépirodalmi Könyvkiadó, 1987).

68 Benedek, supra $n$. 27, at 248.

69 Richard Sherwin, Intersections of Law and Culture. A cross-disciplinary conference hosted by the Department of Comparative Literary and Cultural Studies. (Franklin College Switzerland, Lugano, October 2, 2009).

70 Benedek, supra $n .27$, at 250.

71 N. J. Kandinszky, Attila Schmidt, Dr., Dr. Bárándy György ügyvéd taláros történetei [Talaric Stories by Dr. György Bárándy] (Budapest, Pult Kft., 2006).

72 Béla Ujváry (ed.), Hétröl-hétre a miniszterelnökkel: Gyurcsány Ferenc [From Week to Week with the Prime Minister: Gyurcsány Ferenc] (Budapest, DELA Könyvkiadó Kft., 2006); and Igor Janke, Hajrá magyarok! - Az Orbán Viktor-sztori egy lengyel újságiró szemével [Go for it Hungarians: The Victor Orbán Story through the Lenses of a Polish Journalist] (Budapest, Rézbong Kiadó, 2013).

73 See for instance: Péter Kende Dr., Titkos magyar szolgálatok [Secret Hungarian Services] (Budapest, Hibiszkusz Könyvkiadó Kft., 2004).

74 C. Northcote Parkinson, Parkinson törvénye vagy az Érvényesülés Iskolája [Parkinson's Law: The Pursuit of Progress] (Budapest, Minerva, 1990).

75 See lawyer jokes. E.g.: Csaba Fenyvesi, $A$ jog humora [The Humour of Law] (Pécs, Kódex Kiadó, 2003).

76 See: Péter Föld S., Nagyon rendör viccek [The Very Best of Police Jokes] (Budapest, Edit \& Press Bt., 1997).

77 József Pogány, Mosolygó közigazgatás [Smiley Public Administration], 7 (Budapest, Magyar Távirati Iroda, 1934).

78 Heinrich Böll, $A$ hagyaték [Legacy], 124 (Budapest, Magvető Kiadó, 1984).

79 Ibid. 154.

80 Gábor Lenkei, Vegyünk bankot! [Let’s buy a bank!] (Budapest, Kávé Kiadó, 2002).

81 István Kerékgyártó, Vagyonregény [The Book of Riches] (Budapest, Magvető, 2001).

82 No one is going to think about what kind of degree was requested for Chervyakov - the main character of Chekhov's The Death of a Government Clerk - to fill the position of a will executor.

83 Count József Gvadányi, Egy falusi nótáriusnak budai utazása... [The Village Notary’s Journey to Buda] (Komárom and Pozsony, 1787).

84 Antal Szerb, Magyar irodalomtörténet [Hungarian History of Literature], 326 (Budapest, Magvető Könyvkiadó, $5^{\text {th }}$ edition, 1972).

85 See: Márton Falusi, Esszé a jó kormányzásról [Essay on Good Governance], 55-74, in Balázs Fekete, István H. Szilágyi (eds.), Iustitia modellt áll [A picture of Iustitia] (Budapest, Szent István Társulat, 2011).

86 Mór Jókai, A régi jó táblabirák [The Good Old County Judges] (Szentendre, Mercator Stúdió, 2006). 
87 László András, Egy medvekutató feljegyzései [Notes of a Bear Researcher] (Budapest, Nyitott Könyvműhely Kiadó Kft., 2010).

88 Zsolt Koppány Nagy, Nem kell vala megvénülnöd 2.0. [You Shouldn't Have Grown Old 2.0] (Budapest, Magvetö, 2014).

89 Jókai, supra n. 88, at 6 . 